\title{
ІЗГІЛІК ФИЛОСОФИЯЛЫҚ ҰҒЫМ РЕТІНДЕ
}

\author{
Абдигалиева Лаура Исупкановна \\ laura_abdygaliev@mail.ru \\ Сейфуллин атындавы ҚазАТУ (Нұр-Сұлтан, Қазақстан)
}

\author{
Abdigaliyeva Laura \\ laura_abdygaliev@mail.ru \\ S. Seifullin Kazakh Agrotechnical University (Nur-Sultan, Kazakhstan)
}

\begin{abstract}
Aңдатna. Мақалада Адамзаттың дүниеде болуы оның рухани құндылықтарымен анықталатындығын XXI ғасыр үшін жер тағдырын шешер негізгі мәселелердің бірі екендігіне назар аударады. Адамзат болашағын бағыттауға қажетті рухани күш, ізгі ілім, нақыл сөз, өшпес үлгідегі ақыл-кеңестердің көне мұралардан табылып, танылуы - ұлттық мәдениетіміз, тіліміз бен діліміздің және дініміздің бүгініне, ертеңіне де негіз әрі тірек болар ұлылардың ұрпақпен сабақтастығының заңды құбылысы екендігінің дәлелі ретінде қарастырылады. Көне түркі құндылықтарынан бастау алып, қазақ дүниетанымы мен мұсылман ілімі дискурсынан өрбіген ізгілік (гуманизм) ілімін мақалада қазіргі философиялық танымдық дамудың неғұрлым қажетті әрі маңызды бөлігі ретінде қарастырады. Мақала ұлттық ізгілік ұғымы арқылы философия тарихын тереңірек әрі кеңірек тануға көмектеседі.

$\boldsymbol{T}_{\boldsymbol{Y}} \boldsymbol{u} і \boldsymbol{н}$ сөздер: дүниетаным, философия, ізгілік, ізгі гуманизм, игілік, ойшылдық ізгілік, ізгі.
\end{abstract}

\section{Kipicne}

Тарихтың «Рухани Жаңғыру» деген атпен қалыптасып келе жатқан осы бір даму кезеңінде адам шынайы өмірдің неғұрлым жаңа байланыстары мен қатынастарын аша түсіп, адамзат үшін маңызы бар қырларын жалпы түсінікпен білдіруге талпынады. Ғылымы мен білімі, мәдениеті мен өнері көркейген түркі-мұсылман өркениеті кеңістігінде міне, осындай жағдайдың объективті шарттары қалыптасты. Осы кезеңде, адам баласы қоғамның рухани болмысынан көрінетін тіршілік үшін маңызы бар адам мен адам, адам мен қоғам байланысының адамзаттық табиғатын бейнелейтін сапасын анықтап, оның өміріндегі мәнін тануды міндет қылды. Бұл талпыныс - адамзат құқығын қорғап, еркіндігін қолдаған жаңа рухани серпілістің алғашқы нышаны еді. Бұл қозғалыс - орта ғасыр әлемі үшін тың және өмірді жаңаша қабылдауға, жаңаша құруға негізделген батыл, яғни тек сөз, идея, ұран, қиял формасында ғана емес, іс-әрекеттен де 
жалғасын тапқан жағымды қозғалыс еді. Міне, осындай ой мен істегі жаңа серпілістің өзегі, оған дем беріп, жан салушы ілім - ізгілікті зерттеу ісінің игі нәтижесі де жоқ емес. Бұл қадам, біріншіден, қазіргі рухани жаңғыру кезеңінде қазақ дүниетанымының рухани негізін танып, түсінуімізге көмектеседі. Екіншіден, өркениет кеңістігінде қазақ ғұламалары қалаған жаңа түсініктің тілін, тінін, философиялық мәнін түсіну арқылы адамзат тарихындағы маңызын ашып, рөлін бағалауға қол жеткізуге талпыныс жасау. Осылайша, барлық өркениетке тән гуманистік ой-пікірлер мен идеяларының түркі-мұсылман дүниетанымындағы бейнесін тапқан болар едік.

Ертеден негізі қаланған түркі тайпаларының мәдени құндылықтары VIII-XII ғасырлардағы мұсылман өркениеті қанатының астында ерекше қарқынмен дамыды. Ізгілік те осы бір өркениеттік қарқынның бір ұшқынынан өршіген өміршең ілімге айналды. Ізгілік сөз формасынан озық ой-пікір, іс-әрекет, қозғалыс формасына өте бастады. Диалектиканың абстрактылықтан нақтылыққа өту заңдылығы жолын ізгілік те жүріп өтті. Осылайша, ізгілік біртіндеп жалпыадамзаттық сипат ала бастады.

Жалпыадамзаттық дейтініміз, ізгілік - адам баласының өз ақыл-ойы мен біліміне, ерік-жігер күші мен қайтпас қайсар рухына деген сенімді қуаттайтын, адам болмысының тіршіліктегі орны мен рөлін нақтылап және адамның бақыты мен бостандығын қорғайтын озық идеяларды дүниеге әкелген жаңа күш, жаңа құрал қызметін өмірдің бар саласынан көрсете алған қозғалыс та. Ізгілік - жаңа күш, құрал ғана емес, ол - ескі мен жаңаның синтезі әрі өмірдің өзі де. Міне осы қажеттіліктің рухани табысатынына төменде әлі де тоқталамыз. Ендігі маңызды сұрақ - ізгілік ілім ретінде ғылымға, өмірімізге қажет пе? Ізгілік адамға не бере алады? Бұл сұрақтарға жауап алдында: «»Гуманизм», «гумандылық» және басқа да ұқсас сөздердің қазіргі қолданыстан жоғалып бара жатқандығын байқау қиын емес. Бұл немен байланысты...», - дей келе, философ А.Б. Наурызбаева бұл жағдайды бір қырынан, гуманизм ұғымының қазіргі тіл жүйесінде «архаизм» деп аталатын топқа өтуімен деп түсіндірсе, екінші жағынан құдай «өлімін» мойындаудан туындаған адамның «жоғалуымен» байланыстырса, қазіргі жаңа мәдениетте оған басқа эквивалент табылуы мүмкіндігін білдіреді [1, 4 б.]. Біздің мақсатымыз - тарихи дамуымызда «көрінбей» келген кұндылықтарымыздың адамзаттық, гуманистік сипатын білдіретін ізі бар болса, соны анықтау, тану, әсіресе, адамның «Мендік» бейнесі көмескілене бастаған XXI ғасырдағы бұл ізденісіміз құба-құп дейтін игі істен. 


\section{Зерттеудің әдіснамасы}

Қойылған міндеттерді шешу отандық және шетелдік ғалымдардың кең ауқымды зерттеулеріне, ғылыми танымның жалпы әдіснамасына сүйенеді. Философиялық және әлеуметтік-ғылыми мәтіндерді зерттеуде салыстырмалы-тарихи және тарихи-философиялық талдау әдістері кеңінен қолданылды.

Сонымен қатар, зерттеудің эмпирикалық және теориялық, субъективті және объективті, абсолютті және салыстырмалы, қосымша, эпистемологиялық компоненттері ретінде ұсынуға мүмкіндік беретін философиялық, тарихи, философиялық-антропологиялық, әлеуметтікфилософиялық, мәдени-типологиялық тәсілдердің әдіснамалық синтезіне негізделген жүйелік-интегралды, интегративті тәсіл толық қолданылды.

Зерттелетін мәселені талдаудағы жемісті әдіснамалық құрал тарихи және логикалық, әлемнің бірлігі мен алуан түрлілігінің сәйкес келуі, ізгілік (гуманизм) мәселесін тұжырымдамалық шешудің адам өмірінің дүниетанымдық, өркениеттік-құндылық, танымдық-әдіснамалық және әлеуметтік-практикалық аспектілерімен байланысын қарастыруға мүмкіндік беретін белсенді тәсіл болды.

\section{Ізгілік ұвымы туралы талдау}

Расында, бүгінгі өмірімізбен тамырлас, тағдырлас тарих құндылықтарын тауып, оларды өзімізге де, өзгелерге де танытуға ықпал етіп, оларды ұрпаққа жол көрсетер өміршең, өлмес ілімге айналдыруды қажет етсек, жарқын болашағымызға тірек болар күш-қазына көзін тауып ашқан игі істің негізін қалаған болар едік. Міне, осындай заңды құбылыс көзінің бірінен саналған мұсылман өркениеті кеңістігінде қалыптасқан адам болмысына тән құнды әрі өмірмәнді ілім - ізгілік, ойының өткірлігімен және ақиқаттылығымен, мазмұндылығымен әрі жан-жақтылығымен қазіргі философия тарихы үшін тың тақырып. Әр алуан мәдени-идеялық бұлақтардан бастау ала отырып, өнер мен ғылымның бар саласымен біте қайнаса қалыптасқан бұл құдіретті іліммен, заманымыздан IX-XIII ғасырлар бұрын өркениет кеңістігінде тыныстап кеткен қазақ ғұламаларының еңбектерінсіз таныспын деп айту мүмкін емес. Зерттеудің басты нысаны адам бойындағы зұлымдық тамыры - небір жауыздық, арамдық іс-әрекетке апарар айуандық сезімді жеңер бір-ақ жол - ізгілік жолын тілге тиек етіп, оны ілім ретінде мәнін ашу, талдау және ізгіліктің түрік-мұсылмандық сипатын айқындау.

«Ізгілік» сөзінің өзі түсінік, ұғым ретінде қазақ философиясында қолданылмайды. «Ізгі» мен «ізгіліктің» мағыналық, мәндік 
анықтамасын нақтылау үшін сөздің этимологиясын лингвистикалық сарапқа салғанымыз дұрыс. Арнайы әдебиеттерде, оқулықтарда «ізгілік» - игілік, қайырымдылық, жақсылық сөздерімен синонимдес, ал «ізгі» игі, асыл, жомарт, игілікті, мейірбан, нұрлы, әзіз сөздерімен мағыналас қолданылады. «Ізгі» сөзінің орыс тілінен аудармасы 1954 жылы баспада жарық көрген орыс-қазақ сөздігіне төмендегідей берілген:

«Благой - игі, ізгі,

Благое намерение - игі тілек, ізгі ниет» [2, 48 б.];

«Благонамеренность - ізгі ниеттілік, жақсы ниеттілік»;

«Благонамеренный - ізгі ниетті, жақсы ниетті, ресми түрде ойлайТЫн»;

«Благородство - игілік, адамгершілік, бекзаттық

«Благоразумие - саналылық, естілік, ақылдылық» [2, 49 б.].

Ізгілік, ізгі сөздерінің мағынасы адамның адамға, қоғамға қатысты жақсы табиғатын, жағымды қатынасын, игі ықпалын білдіреді. Ойымызды нақтылау үшін бұл аударманы баспадан соңғы шыққан «Үлкен қазақша-орысша, орысша-қазақша» сөздіктегі «ізгілік», «ізгі» сөздерінің мағынасымен салыстырып көрелік (Бектаев К) :

«Ізгі - благой; добрый; идеальный, благожелательный; благородный; Ізгі есім - доброе имя;

Ізгі кісі - благородная личность;

Ізгі ниетті - благонамеренный;

Ізгі ниеттілік - благонамеренность;

Ізгі одақ - священный союз;

Ізгілік - добро;

Ізгі ниеттілік - доброжелательность» [3, 49 б.].

Енді, орыс тілінен қазақ тіліне аударылған ізгілік сөзінің мағыналарын сараптап көрелік:

«Благородный - ізгі, асыл, жомарт;

игілікті, мейірбан, нұрлы, әзіз» [3, 511 б.];

«Благожелательный - ізгі; мейірбанды; ниеттес»;

«Благонамеренный - ізгі ниетті, жақсы ниетті»;

«Благой - ізгі»;

«Благоволить - ізгілік ету» [3, 511 б.].

«Ізгі» сөзінің орыс-тіліндегі жиі қолданылатын баламасы - «благой», «добрый», ал «ізгілік» - «добро» мағынасын береді. Есімізге түсірсек, 
«добро» - көне Шығыс діни-философиялық ағымдарының негізгі дүниетанымдық сұрақтары ретінде қолданылып келген ұғым. Бұл ұғым адам болмысына тән күрделі рухани құбылысты, оның өзгеруін, ауысуын, тұрақталуын білдіреді. Бұл ретте көне Үнді мұраларының бірі - «Дхаммапададан» үзінді келтіріп көрелік. «Ізгілік жетілгенше, ізгі зұлымдықты да көреді. Бірақ ізгілік жетілген кезде, ізгі ізгілікті көре алады» [4, 441 б.].

Мұнда берілген «благой» мен «благо» ұғымдарының мағынасының арақатынасы өте күрделі. «Благо», яғни ізгілік - адамға жылдам даритын қасиеттен емес, ізгіліктің адам болмысында пісіп жетілуіне белгілі бір уақыт пен жағдайдың қажеттігі анық. «Ізгілікті» «ізгіден» әлдеқайда кең әрі терең ұғым ретінде береді. Көне үнді философиясы «зло», яғни зұлымдылық ұғымын - ізгіліктің қарама-қарсы жағы ретінде қолданған. Түсінгеніміз - «ізгі» адам «ізгілік» дәрежесіне толық жетілмейінше, зұлымдықтан құтыла алмайды немесе зұлымдыққа қарсы тұра алмайды. Сонда «ізгілік» жай сөз ғана емес, белгілі бір рухани жағдайда адамның жан дүниесіне тән ішкі куат, күш есебінде.

«Ізгіліктілік» түсінігін - «ли» ұғымында бейнелеген Конфуций ілімінде «ізгілік» мағынасы үнді дүниетанымынан тереңірек. Философ C.Е. Нұрмұратов әлемдік рухани құндылықтардың тарихын талдау барысында көне шығыста адам мәнінің «бес тұрақтылықтан» (у чан) қалыптасатындығына ерекше мән бергендігін атап өтеді. Олар: жэнь (адамгершілік), и (әділеттілік), ли (ізгіліктілік), чжи (даналық), синь (шынайылық) [5, 5 б.]. Яғни, адамдықтың мәнін құратын бес тұрақтылықтың бірінен саналған «ізгіліктілік» мағынасы енді жеке адам қасиетін білу қызметінен жоғары көтеріліп, күрделене түседі. «Ізгіліктілік» сипаты жекеліктен гөрі жалпылықты білдіретін ұғымға өте бастайды.

Енді, «игілік» пен «ізгілік» ұғымдарының арақатынасын ашып көрсетсек, олардың мән-мағынасы жағынан ұқсастығы бар. Біріншіден, екі құндылық органикалық байланыста. Олар бірін-бірі толықтырып, бірінбірі демеп отыратын, біріне-бірі жол ашып беретін құндылықтар. Мұндай іс-әрекеттерде біріншіліктің ізгілікке тиесілі жағдайын Әл-Фараби былайша ескереді: «Адамның игі қылықтары мен жақсы әрекеттерін жасауға көмектесетін жан қасиеттері - ізгілікті қасиеттер, ал адамның пасық істеpi мен оңбаған әрекеттер жасауына себепші болатындары - сұрқиялық, кемшілік немесе опасыздық болып шығады» [6, 188 б.]. Бұдан шығатын қорытынды: игі іс-әрекет - ізгіліктің нәтижесі. Демек, ізгілік игіліктен кеңірек әрі тереңірек ұғым болып келеді.

Игілік - істің ақыры, пайдалы ақыры. «Қандай да болсын бір зат бақытқа жету үшін пайдалы болғанда ғана игілік болады, ал оған қалай да болса бөгет жасаса, ол жауыздық болады» [6, 213 б.], - дейді Әл-Фараби, кез-келген объектінің мәні бақытқа қатысты анықталатынына сенімді. 
Яғни, игілік - бақыт өлшемі, әрі бақытқа жеткізер күш. «Нағыз игілік қана [iзгі] игілік болмақ» [6, 333 б.], - деген тұжырымында ғұлама игіліктің нағыз болмысының ізгі сапасымен анықталатындығын білдіреді.

Философия тарихына көз жіберсек, жалпы дүниетанымдық көзқарастардың қалыптасуы барысында «ізгілік» ұғымының «благо», «добро» баламаларын кездестеріміз. Егер, бұлар мағынасы ұқсас ұғымдар болса, «благородный», «добрый» сипатындағы тұлғаның өмірдегі танымдық әрекеттері мен ой-пікірлерінің екінші тұлғаға қатынасының қазақ философиясында «ізгілік» ұғымымен трансформациялануын маңызды қадам деп қабылдауымыз қажет. Қай адамзат тобы, қауымы қай кезеңде болмасын - Адам кім? Адам не үшін өмір сүреді? Өмірде не қымбат? т.с.с., шешуін таппай келген бұл сұрақтарға ойланбай, өз тарапынан жауабын айтпай өтпеген. Адам өмірінің маңызды қырының - ізгілік және зұлымдық, олардың арақатынасы мәселесі де қазақ философиялық танымында кеңінен орын алған. Түркі-мұсылман өркениетіне дейінгі уақытта бұл мәселеге қатысты көптеген қанатты сөздер мен құнды ойпікірлер айтылған. Бұған өмірімізге таптырмас серік болар - мақалмәтелдеріміз дәлел. Бұл жерде «ізгі», «ізгілік» қолданыста көбінесе сөз қызметін ғана атқарып келгенін ескере кеткен жөн. Ал, «ізгі» мен «ізгілік» түсініктерін - философиялық ұғымға баламалаудың қандай себептері бар, сол деректерді сараптап көрелік.

«Ізгілік» сөзін ұғым ретінде қолдануға талпыныс түрік-мұсылман кезеңінде ерекше байқалды. К. Мақұлбаева «Дін - рухани азық, дін адамның өміріндегі құбылыстарды қорытып, адамның қасиетіне байланысты ұғымдарды жасады. Қазақ өмірінде де дінге сенушіліктен тұған ұғымдар аз емес... Адамгершілік, сенімділік, қайырымдылық, мейірімділік, ар, ұят, ождан, міндеттілік, дербестілік, парасаттылық, ізгіліктік істер жасау, жақсылық, біреудің жаны мен тәніне азап бермеу, адам деген атқа лайық болу т.б. имандылықты қалыптастырады, руханилықтың гуманистік мазмұнын қалайды» [7, 136-137 б.]. Адам болмысының рухани құндылықтарының ішінен ерекше көрінген «ізгі», «ізгілік» ұғымдары Қасиетті Құран кітабында өте жиі қолданылуына сәйкес, сол кезең үшін маңызды ілімнің, жалпы адамзаттық ілімнің негізін қалаған терең ұғым ретінде қоғамдық санада қабылданды. «Қайырымды қаланы» әл-Фарабидің «ізгі» қала, кемелденген жанды Ж. Баласағұнның «ізгі» жан, сопылық жолын Қ.А. Иассауидің «ізгілік» жолы деп алу мәнісі де осы бір «ізгілік» ұғымына қатысты өзгерістермен, рухани өркендеумен байланысты.

Сараптап қарасақ, «ізгі», «ізгілік» ұғымдарының мағынасы күнделікті қарапайым қолданыстан әлдеқайда терең. Сондықтан, «ізгілік» ұғым емес, жай сөздердің қатарынан деп пікір айтушылармен келісе алмаймыз. 
Себебі, «ізгі», «ізгілік» сөздерінің философиялық ұғым ретінде қолдану бастамасы түркі-мұсылман ойшылдарынан басталған. Әбу Нәсір әлФараби, Ж. Баласағұн, Қ.А. Иассауи сынды ғұламалар «ізгі» сөзін терең түсінік, ұғым формасында зерттеу нысанасына айналдырды.

«Ізгілік не?

Тегі қандай, түсі қандай?

Мінез-құлық, ісі қандай өзінің?» [8, 124 б.]

деп, ақын Ж. Баласағұнның «ізгілікті» - танып, білу қажет маңызды ұғым ретінде түсініп, жеткізуге талпынысы - «ізгіліктің» философиялық категория ретінде толыққанды қалыптасуының басы десек те болады. Ойшылдың, жоғарыда келтірілген бәйіттегі сұрақ қойылымы ізгіліктің табиғатының күрделілігін білдіреді. Ізгілік - ойшыл үшін жұмбақ құбылыс. Мұнда, «ізгілікті» ұғым ретінде түсініп, қабылдауымызға ықпал ететін бір көзқарастың қажеттігі мәселесі өздігінен бой көтереді. Бізге жеткен түркілік-мұсылмандық құндылықтардың біркелкі еместігі жағдайы, «ізгілікті» - ұғым ретінде теориялық-танымдық сипатын анықтауымызға аздап кедергі келтіреді. Бұған, өзіміз жоғарыда келтірген деректеріміз де қосылады. Мәселенің мәні - ізгіліктің игілік, қайырымдылық сияқты адамның жақсы қасиетінен танылып келуінде.

\section{Түркі-мұсылман вұламалары ізділік жсайында}

Ғұлама, ғалым әл-Фарабидің ізгілікке қатысты саяси-этикалық ұстанымдарымен ойымызды жалғастырамыз. Әл-Фараби «Бақытқа жету туралы» еңбегінде төрт түрлі ізгілікке тоқталып, әрқайсысын жеке сараптайды. Бұлар - теориялық, ойшылдық, этикалық, практикалық ізгіліктер. Трактатта қолданылған «ізгіліктің» сөз емес, кең ұғым екендігін: «Теориялық ізгіліктер дегеніміз түпкі мақсаты - өмірде бар нәрселерді зерттеу болып табылатын және пайымдаудағы (мазмұны) өзінің көздеген мақсаттарын ғана қамтитын білімдер» [6, 297 б], - деп берген философтың анықтамасы дәлелдейді. Әл-Фарабидің пікірінше, бұл білімдердің әуел бастан көңілге тоқитыны, және оған қарсы жағы да бар. Сонымен қатар, мазмұны күрделі болып келетін - «ойлап, тексеріп, зерттеп, үйреніп, оқу» [6, 297 б] әдісімен келетін білімдер де бар. Теориялық ізгілікті біліммен байланыстыра түсіндіруі VIII-XII ғасырлардағы түркі-мұсылман әлеміндегі саяси-ағартушылық қозғалыстың ғалымға игі ықпалын білдіреді. Бұл ықпал әл-Фарабидің келесі тұжырымдарынан анық көрінеді: «Ойшылдық ізгілік дегеніміз - әлденедей бір ізгі мақсатта барынша көп пайда келтіретін нәрсені анықтауға жұмсалатын ізгілік. ... Егер де ойлау қабілеті жалған болса игілік жолында барынша көп пай- 
да келтіретін нәрсені анықтау үшін жұмсалатын болса, онда бұл қабілет ойдағы жалған ізгілік болғаны».

«Ең пайдалы және ең әдемі нәрсе» ізгі мақсатқа қажет, ал «ізгі мақсаттағы ең әдемі нәрсе - ізгілікті құрайды. Мұндай ойшылдық - ізгілік ойшылдық, азаматтық ізгілік болып табылады» [6, 329-330 б.]. Әл-Фараби ізгілікті философиялық категория ретінде табиғатын, танымдық дамудағы орны мен рөлін анықтауды объективті шындық пен санадағы жалпы мен жекенің өзара байланысы негізінде шешеді. «Ізгі» ұғымының мағынасы халыққа пайда келтіру мақсатында қолданылады. Сондықтан ғұлама «ізгі мақсаттағы ең пайдалы нәрсе» және «ең әдемі нәрсе» деген сөздердің арасында айырмашылық жоқ» [6, 330 б.] деген қорытындыға тоқталады. «Пайда» және «әдемі» сөздерінің мағынасы «ізгіге» қатысты теңеледі. Мұнда «ізгінің» ұғымының басымдылық рөлі анық байқалады. Тұлғаның рухани әлемінің қалыптасуы ізгілікпен өлшенеді. Осыған байланысты, субъект не жалған, не адамзаттық бағытқа бұрылуы тиіс.

«Егер оның ойшылдық ізгіліктері жеке мақсаттағы және жеке жағдайлардағы ең пайдалы заттармен ғана (шектелетін) болса, онда оның этикалық ізгілігі де осыған сәйкес келуге тиіс. Ойшылдық ізгіліктер жетекшілігі неғұрлым кемелді болса және бұларда бар нәрсе неғұрлым күшті болса, осымен ұштасатын этикалық ізгіліктер жетекшілігі соғұрлым толық, соғұрлым күшті болмақ» [6,333 б.]. Бұл түйін әл-Фарабидің философиялық көзқарасының идеалистік сипатын бейнелейді. Этикалық ізгіліктер ойшылдық ізгіліктерге бағынады. Ой этикалық іс-әрекеттерді бағыттап, бақылай алатын күшке ие. Бұл жерде ой басым рөлді атқарады. Міне, сондықтан ғұлама білім мәселесіне көбірек көңіл бөледі. Бірақ ғұлама ойы практикалық ізгіліктің дәрежесін төмендетуден аулақ. «Ең күшті ойшылдық ізгілік пен ең күшті этикалық ізгілік бір-бірінен айырғысыз» [6, 338 б.], - деген пікірінде әл-Фарабидің, ғылым мен білім өркендеген орта ғасырда тәрбиенің орнын көтеруі заңды. Осылайша, ғұлама «ізгілік» түсінігімен бірге, адам мен әлемді тану көзі деп қабылдаған «ақыл» түсінігімен байланысты тұлғаның кемелденуі, арождан, құқығы жайлы Ренессанстық жаңа көзқарастың негізін салды.

Ерік пен ізгілік адам болмысының өзара байланысты әрі маңызды қажеттіліктері. Ерік - ізгілік үшін маңызды шарт. Ізгілік те, өз кезегінде еріксіз, адамдық сипатқа толыққанды өте алмайды. Ерік пен ізгіліктің арақатынасы жөнінде: «Ерікке негізделген ізгілік адамдық ізгілік болмақ, адам ерікке негізделген басқа заттарды алардағы жолмен осыған жеткенде адамзатқа тән ойшылдық ізгілікке ие болады» [6, 340 б.], - деп түйіндеген ғұлама ізгіліктің еріксіз адамдық табиғатынан айырылар мүмкіндігі де жоқ еместігін мойындайды. Осылайша, әл-Фараби «ізгілік» ұғымын этикалық мазмұнмен байытады. «Ізгілік» ұғымының шекарасы өте кең, 
ауқымды. Міне, сондықтан, кез-келген адамда өнер, этика, ойшылдық ізгіліктері бірдей күшті бола алмайтынын ескертеді. Ғұлама үшін ізгілік - жеке индивидке тән немесе біртіндеп даритын қасиет қана емес, ол жалпылық формаға өте алатын күрделі әрі қозғалмалы құбылыс, қозғалыс. Қозғалмалы деп түсінетініміздің себебі: ізгілік бірден пайда болмайды немесе толық тұрақтап та қала алмайды. Ізгіліктің тұрақтылығын уақыт пен кеңістік ішінде шешетін субъект - адам, қауым, қала, тіпті халық та болуы мүмкін.

«Үйрету дегеніміз - халықтар мен қалаларға теориялық ізгіліктерді дарыту деген сөз. Тәрбиелеу дегеніміз - халықтардың бойына білімге негізделген этикалық ізгіліктер мен өнерлерді дарыту деген сөз» $[6,342-$ 343 б.]. Мұнда, әл-Фараби «ізгілік» ұғымының қолданыс кеңістігін одан әрі кеңейте түседі. Әл-Фараби тұңғыш болып ізгілік ұғымына қажетті әрі маңызды категория - білім жөнінде ой тастайды. Ізгілік ілімінің маңызды компоненті ретінде - білімнің адамның жетілу жолындағы рөлін одан әрі дамытқан ақын Х.Х.Ж. Баласағұн еді. Даланың ақиық ақыны терең танымы - осы ізгілік ілімін зерделейді. «Ізгілік» ұғымының ілім ретінде дамып, өрбу тамырының бір ізі Ж. Баласағұннан басталады.

«Бұл - ізгілік - шын асыл,

Асылға үйір шын асылдар туасы!

Асыл - дара, кім жасырар, таласар?!

Қолға тисе, барша адамға жарасар» [8, 128 б.].

Ақын, ізгілікті асылға теңейді. Яғни, ізгілік ұмытылмайды, тозбайды, жоқ та болып кетпейді. Мұнда ақын ізгіліктің мәңгіліктік құбылыс, қозғалыс екендігіне сенімді болса,

«Ізгі іс - елдің мақтаны,

Тек ессіздер сөйлеп, сөгіп жатқаны» [8, 82 б.], - деп келетін 909-шы бетінде, ізгіліктің қоғамдағы объективті жағдайын жайып салады. Ақын түсінігінде, ізгілік - абсолютті құбылыс емес. Ізгіліктің қарама-қарсы жағы ессіздікке де қатысты, ізгіліктің де барлығына бірдей мүмкіндік пен ерік берілген. Оның ерік негізінде мүмкіндік кеңістігінде тұрақталуына ақын атаған негізгі сегіз категория жағдай жасай алады. Ізгі ой, ізгі сөз, ізгі тіл, ізгі көңіл, ізгі жүрек, ізгі тірлік, ақыл, білім - міне осы мағынасы терең түсініктер - категориялар қызметінде ізгіліктің тұрақтылығын қамтамасыз етеді. Ж. Баласағұнның ұғымындағы «кемелді», яғни «жетілген» адам - міне, осы сегіз қасиетті өзіне толық дарытқандығы нәтижені көрсетеді. Будда дініндегі, барлық қайғы мен қасіретке қарсы 
тұра алатын адамның тірек қылар сегіз жолы, ақын арман еткен ізгілік жолымен ұқсас. Бұл да ізгіліктің қарапайым емес табиғатын танытады.

Қазақ ғұламалары адамгершілікке, имандылыққа негіздеген әдеп түсінігінің өрісі кеңейіп, жаңа мазмұнға ие болды. Бұл - шынайы гуманист ойшылдарына ғана тән үлкен ерлік, жемісті еңбек, терең білім, биік таланттың жарқырап ерекше көрінген кезеңі. Осылайша, гуманизмнің ерте заманнан өзіндік ерекшеліктерімен қалыптасып келе жатқан дәстүрлі дамуы, енді, мұсылман өркениетінің қанатының астында бұрын болмаған биікке көтеріліп, жаңа ілімнің қалыптасуына ықпал жасады. Ізгілік деп аталатын жаңа ілімді, жаңа ұғымды дамытуда, оның теориялық негізін тереңдетіп, даярлау еңбегінің мұсылман өркениетінің озық ойлы ғұламаларына тиесілі екенін мойындауымыз қажет. Әрине, адамзат баласы үшін күні бүгінге дейін құнын жоймаған, ғылымның бай ғылымитеориялық негізін қалап кеткен грек өркениетінің орны бөлек. Қарамақайшылыққа толы орта ғасырлық кеңістікте жақсы мен жаманның, әлсіз бен күштінің, білімді мен білімсіздің, дана мен наданның арасындағы күрес объектісіне айналған ізгілік ілімі әділетсіздік пен теңсіздік әлеміне қарсы күреске шықты.

«Құтты білік» дастанындағы ізгілік ілімі - ислам құндылықтарының түркілік дүниетанымдық ой-пікірлерімен синтезінен қаланған. Ақын түркі халықтары әдебиетінің тарихында тұңғыш рет ізгілік мәселесін көркем сөз өнерінің зерттеу объектісі ретінде қарастырады. Ж. Баласағұнның өзіндік өмірлік тәжірибесі ізгілік іліміне қажетті құрылыс материалы іспеттес.

Түркі-мұсылман өркениетінде ізгілік ұрығын сепкен қазақ даналарының философиялық дүниетанымын зерттеу барысында философтар Ә. Нысанбаев, Б. Сатершиновтың: «Ұлттық философияның ерекшеліктері қазақ сахарасының топырағынан өсіп өркендеген Ұлы дала ойшылдарының - Тоныкөк пен Қорқыттың, Жүсіп Баласағұн мен Махмұт Қашқари, Иассауи мен Иүгінекидің қазақ жыраулары мен зар-заман ойшыл ақындарының, Абай мен Шәкәрімнің дүниетанымдық ілімдерінің өзегін құрайды» [9, 4 б.], - деген құнды пікірі қазақ дүниетанымының адамзаттық мәнін білдіретін тың әрі маңызды қырын өте орынды ескерген.

Кешірек қолға алынса да, кеңінен бой жаза бастаған осы бір тартымды тақырып төңірегіндегі игі іске үлес қосқан отандық зерттеушілеріміздін бірі O.А. Сегізбаев зерттеу еңбегінде: «Қазақтарда философия басқа халықтар сияқты табиғи түрде қалыптасқан. Ол адамның қоршаған ортаны түсіну, олар қалай өмір сүріп, қандай тұрмыс құрса да оған жақындардың өмірінде оның қандай маңызы бар және қалай көрінетіндігін бейнелеудің қажеттігінен қалыптасты. Қазақ философиясының әлем философиясымен үндестігі бар. Сонымен қатар онда қазақ халқы өмірінің 
ерекшеліктері де бейнеленген. Атап өту керек, мұсылмандық Шығыс өркениеті өзінің гүлдену кезеңінде, яғни IX-XII ғасырларда сол кездегі Батыс Еуропа мәдениетіне қарағанда азаматтық білім мен ғылыми ашулардың кең таралуымен байқалады. Бұл өркениеттің қарастырып отырған саладағы жетістіктері, дәл осы өркениет көмегімен батыс еуропалық ғалымдардың бірте-бірте теология үстемдігінен босанып, өз қатарынан Қайта өрлеу және Жаңа дәуір алыптарын тудырғанын атап өтуімен айқындала түседі» [10, 69 б.], - деп жазған құнды пікірі «Мәселе Әбу Нәсір әл-Фараби, Жүсіп Баласағұн, Қожа Ахмет Иассауи секілді ғұламаларымыздың ілімдерін қайтадан қалпына келтіріп, жаңа, тәуелсіз көзқарас тұрғысынан талдау мен олардың еңбектерінде тұнып тұрған адам тіршілігінің мән-мағынасы туралы ойларын ұлттық санамызға сіңіре білуде» [11, 77 б.] екендігін тұжырымдаған философ Г.Ж. Нұрышеваның ой түйінімен сарындастығы көне түпкөздерге жаңа жағынан келуімізді қостайды.

\section{Ізгілік - философиялық категория ретінде}

Түркі халықтарының дүниетанымы мен діні хақында келелі еңбектер жазған философ Ғ. Есімнің: «Абай ұғымында Алланы сүю адамның жеке басындағы асыл қасиеттерді қастерлеу, адамгершілікті негізгі қағидаға айналдыру, ал ол үшін ең алдымен өзіңді-өзің тазалауың қажет Алланы сүю ізгілікке байланысты жол» [12, 56 б.], - құнды пікірдің қайырымы түп тамыры орта ғасырдағы жаңа рухани серпілістің бір ізімен Абай бастаған ағартушы-қайраткерлеріміздің дүниетанымымен сабақтастығын білдіреді. Ізгілік жолының діни бұтағы ретінде, аталмыш отандық ғалымдарымыз VIII-XII ғасырларды қамтыған түркі-мұсылман өркениетінде дами түскен рухани қозғалыстың жаңа түрін мойындағандардан ғана емес, олар -алғаш болып бағалағандардың қатарынан еді. Ренессанс ұғымын рухтың ерекше бір жоғарылауы, өркениеттік гүлдену, гуманизмнің күшеюі мағынасында қолдануға болатындығы жөнінде философ Ә.О. Төребаев «Құтты білік» сияқты ренессанстық туындылардан іздестіру бағытында игі қадам жасаған. Расында, түркі-мұсылман ғұламаларының дастанындағы гуманистік көзқарастарды зерттеу қажеттігіне Ж. Алтаев, Т. Ғабитов, А. Қасабек, Қ. Мұхамбеталиев атты ғалымдарымыздың төмендегі түйінінен кейін де еш күмән жоқ: «Ж. Баласағұн шығармаларының ренессанстік, гуманистік бастауы, біздіңше, Аристотель мен Фараби философиясы дәрежесіне көтерілген» [13, 146 б.]. Бұл жерде Ж. Баласағұн мұрасының Фараби мен Абайдай толық зерттеліп болмағанын, «Құтты біліктің» таным кеңістігінде енді бой жаза бастаған жайын ескере кеткен жөн. 
«Ізгілік пен зұлымдық - адамның іс-әрекетіне, сондай-ақ қоғамдық құбылыстарға белгілі-бір таптық адамгершілік тұрғысынан бағасы берілетін моралдық-этикалық категориялар. «Ізгілік» деп қоғам (тап) адамгершілікке сай, үлгі алуға лайық де есептелетін түсініктер ұғынылады» [14, 493-494 бб.] - деп философиялық сөздікте келтірілген тұжырым ізгіліктің ұғымдық дәрежесін ғылым кеңістігінде көтере түседі. «Жақсылық пен жамандық, немесе ізгілік пен зұлымдық адамгершілік санасының алғашқы қауымдық құрылыстан бастап қазіргі заманға дейінгі барлық тарихи құрылымына тән бір-біріне қарама-қарсы жұп категориялар» [11, 146 б.] - дей келе, философ Г.Ж. Нұрышеваның ізгіліктің бұрыннан бар категория санатынан екендігін нұсқауына бұл мәселенің әлі жеке тұрғыда зерттелмегенін қоса айтып кетуге болады.

Бұл мәселе жөнінде бүгінгі түрік әлемі не дейді екен? «Құтты білікті» филология ғылымы тұрғысынан терең зерттеген түрік ғалымы Ділашардың «Kutadgu Bilic inselemesi» еңбегінен дастанды философиялық зерттеу саласының тың екенін аңғарамыз. Бұл турасында түрік зерттеушісі Мажмит Arslaw «Құтты білікті» алғашқы болып пәлсапалық көзқараста танытқан неміс ғалымы Отто Албертс пен орыс ғалымы О. Мелиоранский екендігін атап өткенімен, дастанның философиялық зерттелу тарихнамасының түріктік тармағы туралы сөз қозғамайды [15, 62 б.]. Еңбегінің кіріспе бөлімінде M.Arslan, «Құтты білік» 1070 ж. болған Малазғырт (Malazgirt Savasi) соғысынан бір жыл бұрын Қашқарда Юсуф Хас Хажиб атты терең ойлайтын әрі мемлекет адамы болған бір түрік тарапынан жазылғанын және көне түрік тілінде «Мемлекет Басқару Білімі» (Delvet Yönetme B1lg1s1) мағынасында қабылдап, бағаланған бұл шығарманың бірнеше мемлекет қайраткерлері мен билеушілерінің «Басты» кітабы саналып келгендігі туралы келтірген мәліметі еңбектің мазмұнының жан-жақтылығын, маңыздылығын дәйектейді. Бірақ «Құтты білікті» толық оқып, меңгерген жағдайда, оның жалпы адам баласына игі тілекпен, ізгілікті мақсатта жазылған тың қырын байқау қиын емес. Тек, ақынның терең тұжырымдарын талдап, тани алсаң болғаны. Сондықтан да болар, бүгінде, Ж. Баласағұн шығармасын зерттеуге қызығушылық түрік әлемінде де өсе түсуде.

Өз ортасынан озық ақиық даналарымыздың еңбектерін антропологиялық тұрғыдан тереңірек зерттеу әлі талай ой түйіндері мен тұжырымдарды тудырары хақ. Бұл жағынан көне түпнұсқалар әлі де тың.

XI ғасырдың ұлы ғалымы, тіл зергері Махмұт Қашқари «Диуани лұғат-ат түрк» еңбегінде ізгілік ұғымын қолданады. Ғалым ізгіліктің өш, кек ұғымына қарама-қарсы табиғатын анықтай келе, «өміріңде неғұрлым ізгілікті көп жаса» қағидасын тұжырымдайды. Өмір заңы ізгілікке негізделуі тиіс. «Өш-кек барлық кісінің пенде үстіндегі алымы, біл, шама 
жеткенше, қолыңмен көп ізгілік қыл» (өш, кекті пенделерден алынатын алашаң қарыз деп түсін, одан без; соны түсін де мүсәпірлерге, кейуаналарға қолыңнан келгенше жақсылық істе)» [16, 72 б.], - деп адам өмірінің мәнінің ізгілікпен өлшенетіндігіне баса назар аударуы өркениеттік жаңа рухани серпілістің бір ұшқыны десек, қателеспейміз.

Ж. Баласағұнмен замандас өмір сүрген, тарихта өшпес аты мен ізгі жолы қалған ұлы ойшыл, ақын Қ.А. Иассауи ізгілігінің жолы өзгешелеу болғанымен, мақсат-мұраты мұсылман өркениетінің ғұламалары негіздеген бір ізгілік жолында. «Ізгілікті - істіліктің, яғни ақылдылықтың белгісі» деп түйіндеген ұлы шейх адам болмысының адамгершіліктік тазалығы мәселесін сопылық көзқараспен шешеді. Бұл көзқараста жүрек негізгі рөл атқарады.

«Ақылға ерсең, соның өзі бір ғанибет» [17, 208 б.]

деген хикмет жолы Қ.А. Иассауи көзқарасының рационалды сипатын бейнелейді. Ақыл - жол көрсетер күш. Түркі-мұсылман ойшылдарының ой-пікірлерінен кеңінен орын алған, «ақыл - білім - жүрек» одағына қондырылған ізгілік ілімінің бір қарапайым белгілері Иассауи хикметтерінен де орын алған. Түркі-мұсылман гуманистерінің ақыл мен білім одағына жүректі әкеліп қосу себебінің объективті себебі, қуалай келсек, ислам кұндылығына әкеледі.

Ізгілік - қазақ ғұламалары танымының ислам іліміндегі адамгершіліктік-этикалық қағидалармен тығыз байланысынан туған жаңа нәтиже, жаңа із. VIII-XII ғасырларда ізгілік - көкейкесті адамзаттық мәселе деңгейіне көтеріледі.

Міне, қоғамның осы қырын зерттеу ісінің игі нәтижесі де жоқ емес. Бұл қадам, біріншіден, қазақ дүниетанымының рухани жан дүниесін танып, түсінуімізге көмектеседі. Екіншіден, өркениет кеңістігінде қазақ ғұламалары қалаған жаңа түсініктің тілін, тінін, философиялық мәнін түсіну арқылы адамзат тарихындағы маңызын ашып, рөлін бағалауға қол жеткізуге талпыныс жасау. Осылайша, барлық өркениетке тән гуманистік ой-пікірлер мен идеяларының түркі-мұсылман дүниетанымындағы бейнесін тапқан болар едік.

Осы орайда, пікірімізді философ Ж.М. Мүтәліповтің «Ақиқатына келсек, Европа елдері бар болғаны Шығыста туындаған діндер мен ілімдерді өздеріне сай өзгертумен шұғылданған. Осы орайда, әлемге ізгілік жолын сілтеген киелі кітап «Тәуратқа» байланысты дәлелденген ақиқаттың көзін ашып кеткен жөн» [18, 25 б.], - деген құнды тұжырымымен дәйектей аламыз. Яғни, ізгіліктің жеке мәселе ретінде көтерілуіне негізгі себептердің бірі - исламның игі әсері. 
«Үмбет болсаң, құлақ салған, ей халайық.

Жақсылардың ізгілігі дертімізге болсын дауа,

Күнәлары күннен күнге артар достар» [18, 120 б.].

Қ.А. Иассауи хикметі «ізгілікке» басқа қырынан келеді. «Жақсылардың ізгілігі» сөз тіркестеріндегі «ізгілік» мағынасы «жақсы» мағынасынан кең әрі тереңірек. Ізгілік - жақсылардың өмірдегі ізі, яғни іс-әрекетінің нәтижесі бейнесінде суреттеледі.

Түркі-мұсылман ғұламаларының ізгілік мәселесіне қатысты ортақ ой тұжырымдарынан түсінгеніміз, ізгіліктің маңызды атрибуттары - оның ішкі «Мені» және сыртқы «Мені». Сыртқы «Мені» - сол субъектінің ісәрекеттегі, яғни этикалық жағдайының көрінісі. Мұнда адам этикалық субъект ретінде бейнеленеді. Ал ішкі «Мені» - ойлайтын, есті субъект. Ол - рационалды субъект ретінде бейнеленеді. Яғни ізгілікті тек сөз немесе қиял, бір іс-қимылы арқылы ғана білдіру мүмкін емес. Ізгіліктің күрделі табиғаты бұл жерде тағы білінеді.

\section{Қорытынды}

Тұжырымдасақ, ізгілік - бірнеше аспектіде қарап, талдауды қажет ететін категория, философиялық кең түсінік, объективті шындықтың көрінісі ретінде және адамның жетілу көрсеткіші рөлінде зерттелетін объект (нысана) ретінде қабылдануы тиіс ұғым. Бұл үшін, болашақта терең теориялық талдаулар жүргізілуі қажет.

Ізгілікті толық түсіну үшін өзіңді ізгі жан, ізгі тұлға рөлінде қойып көру, елестету қажет пе? Бұл талпыныстар әрине жеткіліксіз. Ізгіліктің түп тамырын суреттеу, эмпирикалық әдістердің күші жетпейтін тереңде жатыр.

Ізгілік түсінігінің күрделілігі жағдайының бір қыры, ізгіліктің сөздіктер мен әдебиеттердегі мағынасының біртекті еместігі. Бірақ «ізгілік» ұғымын кең мағынада бейнелеудің қиындығынан, «ізгіліктің» бүгінгі рухани дүниемізге маңыздылығы, қажеттігі басым түсері анық. Сонымен, ізгілік - адам болмысының ой, қиял, пікір, ілім, іс-әрекет пен ізі арқылы көрінетін күрделі әрі қозғалмалы құбылыс. Құбылыс, ізгілік жеке бір адамға танылған сапа, қасиет, атақ емес, ол бір адамның екінші адамға қатынасынан және адамның қоғамға қатынасынан көрінетін терең философиялық ұғым. Ізгілікті қатынас адамның өзін-өзі жетілдіруі үшін қажет құрылыс материалы іспеттес. Жеке алғанда, адам ізгіліксіз жетілу, кемелдену мақсатына жете алмайды. 


\section{Әдебиеттер тізімі}

1 Наурызбаева А.Б. Гуманизм как концепт антропологического дискурса культуры. - Докт. ғыл. дәреж. алу. дайын. дисс. автореф. - Алматы, 2003. - 53 с.

2 Русско-казахский словарь. - Москва, 1954. - 935 б.

3 Бектаев Қ. Үлкен қазақша-орысша сөздік. - Алматы, 1999. - 704 б.

4 Поэзия и проза древнего Востока. Из Дхаммапады. - 9 глава. - Москва, 1973. - $734 \mathrm{c}$.

5 Нұрмұратов С.Е. Рухани құндылықтардың қалыптасуы мен дамуы. - Докт. ғыл. дәреж. алу. дайын. дисс. автореф. - Алматы, 2002. - 49 б.

6 Әбу Нәсір Әл-Фараби. Әлеуметтік-этикалық трактаттар. - Алматы: Ғылым, 1975. - 364 б.

7 Мақұлбаева Қ.Т. Руханилық және исламдық // Түркістанның 1500 арналған Халық. ғыл. -прак. конф. матер. - Алматы: АГУ им. Абая, 2000. - 1926.

8 Баласағұн Ж. Құтты білік. - Алматы: Жазушы, 1996. - 594 б.

9 Нысанбаев А.Н., Сатершинов Б. Бекасыл Биболатұлы дүниетанымы және философиясы // Адам әлемі. Филос. және қоғ.-гуманитарлық журнал. - 1(27) 2006. - 109 б.

10 Сегизбаев О.А. Казахская философия X-нач. XX века. - Алматы: Ғылым, 1996. $-472 \mathrm{c}$.

11 Нұрышева. Н.Г. Адам өмірі мәні мәселесінің қазақ философиясындағы көрінісі. - Докт. ғыл. дәреж. алу. дайын. дисс. автореф. - Алматы, 2002. - 53 б.

12 Есім Ғарифолла. Хакім Абай (даналық дүниетанымы). - Алматы: Атамұра-Қазақстан, 1994. - 200 б.

13 Төребаев О.Ә. Ж. Баласағұнның әлеуметтік философиясы. - Филос. ғылым. дәреж. алу. дайын. канд. дисс. автореф. - Алматы, 2002. - 24 б.

14 Философиялық сөздік. - Алматы. Қазақ энциклопедиясы, 1996, - 525 б.; Алтаев Ж., Ғабитов Т., Қасабек А., Мұхамбеталиев Қ. Философия және мәдениеттану. - Алматы, 2001. - 292 б.

15 Дос. Др. Дажмит Arslan. Kutadku-Bilicdeki toplum ve Devlet Anlavisi. Istambull: Ede Bivat Farültesı Basımevı, 1987. - 131 б.

16 Қашқари М. Түрік сөздігі. - Алматы, 1998. - 982 б.

17 Иассауи Қ.А. Хикметтер. - Алматы: Дайк пресс, 1991. - 242 б.

18 Мүтәліпов Ж.М. Шығыс пен Батыс өркениеттері сұхбатындағы қазақ мәдениеті: мәдениеттанулық талдау. - Докт. ғыл. дәреж. алу. дайын. дисс. автореф. - Алматы, 2004. - 49 с.

\section{Transliteration}

1 Nauryzbaeva A.B. Gumanizm kak koncept antropologicheskogo diskursa kul'tury [Humanism as a Concept of Anthropological Discourse of Culture]. - Dokt. ғyl. dərezh. alu. dajyn. diss. avtoref. - Almaty, 2003. - 53 s.

2 Russko-kazahskij slovar [Russian-Kazakh Dictionary]. - Moskva, 1954. - 935 b. 
3 Bektaev Q. Ulken qazaqsha-oryssha sozdik [Large Kazakh-Russian Dictionary]. - Almaty, 1999. - 704 b.

4 Pojezija i proza drevnego Vostoka. Iz Dhammapady [Poetry and Prose of the Ancient East. From Dhammapada]. - 9 glava. - Moskva, 1973. - 734 s.

5 Nurmuratov S.E. Ruhani qundylyqtardyn qalyptasuy men damuy [Formation and Development of Spiritual Values]. - Dokt. gyl. darezh. alu. dajyn. diss. avtoref. Almaty, 2002. -49 b.

6 Abu Nasir Al-Farabi. Aleumettik-jetikalyq traktattar [Socio-Ethical Treatises]. - Almaty: Gylym, 1975. - 364 b.

7 Maqulbaeva Q.T. Ruhanilyq zhane islamdyq [Spiritual and Islamic] // TuYrkistannyn 1500 arnalgan Halyq. gyl. -prak. konf. Mater. - Almaty: AGU im. Abaja, 2000. - 192 b.

8 Balasagun Zh. Qutty bilik [Valuable Knowledge]. - Almaty: Zhazushy, 1996. $-594 \mathrm{~b}$.

9 Nysanbaev A.N., Satershinov B. Bekasyl Bibolatuly dunietanymy zhane filosofijasy [Bekasyl Bibolatovich's Worldview and Philosophy] // Adam əlemi. Filos. zhane qog-gumanitarlyq zhurnal. - 1(27)2006. - 109 b.

10 Segizbaev O.A. Kazahskaja filosofija X-nach. XX veka [Kazakh Philosophy X-beginning of the XX Century]. - Almaty: Fylym, 1996. - $472 \mathrm{~s}$.

11 Nurysheva. N.G. Adam omiri mani maselesinin qazaq filosofijasyndagy korinisi [Manifestation of the Problem of the Meaning of Human Life in Kazakh Philosophy]. - Dokt. gyl. darezh. alu. dajyn. diss. avtoref. - Almaty, 2002. - 53 b.

12 Esim Garifolla. Hakim Abaj (danalyq dunietanymy) [Hakim Abai (Worldview of Wisdom)]. - Almaty: Atamura-Qazaqstan, 1994. - 200 b.

13 Terebaev O.A.Zh. Balasagunnyn aleumettik filosofijasy [Social Philosophy of Balasagun]. - Filos. gylym. darezh. alu. dajyn. kand. diss. avtoref. - Almaty, 2002. $-24 \mathrm{~b}$.

14 Filosofijalyq sozdik [Philosophical Dictionary]. - Almaty. Qazaq jenciklopedijasy, 1996. - 525 b.; Altaev Zh., Gabitov T., Qasabek A., Muhambetaliev Q. Filosofija zhane madeniettanu. - Almaty, 2001. - 292 b.

15 Dos. Dr. Dazhmit Arslan. Kutadku-Bilicdeki toplum ve Devlet Anlavisi [Community and State Understanding in Kutadgu-Bilig]. - Istambull: Ede Bivat Farültesı Basımev1, 1987. - 131 b.

16 Qashqari M. Turik sozdigi [Turkish Dictionary]. - Almaty, 1998. - 982 b.

17 Iassaui Q.A. Hikmetter [Wisdoms]. - Almaty: Dajk press, 1991. - 242 b.

18 Mutalipov Zh.M. Shygys pen Batys orkenietteri suhbatyndagy qazaq madenieti: madeniettanulyқ taldau [Kazakh Culture in the Dialogue of Eastern and Western Civilizations: Cultural Analysis]. - Dokt. gyl. darezh. alu. dajyn. diss. avtoref. - Almaty, 2004. - $49 \mathrm{~s}$. 
Абдигалиева Л.И.

Добродетель как философское понятие

Аннотация. В статье обращается внимание на духовные ценности человека, которые определяют суть и смысл существование человечества в современном мире. Признание и обретение духовных сил, учений, притч, бессмертных мудрых советов в наследии поколений рассматривается как закономерное явление преемственности, которое становится основой и опорой нашей национальной культуры, языка, менталитета, необходимых для будущего. Именно поэтому учение о гуманизме, восходящее к древнетюркским ценностям и к дискурсу казахского миропонимания и мусульманского учения рассматривается как наиболее необходимая и важная часть современной философии. Стержнем преемственности в истории казахского мировоззрения является проблема гуманизма, что способствует более глубокому и широкому познанию истории национальной философии.

Ключевые слова: мировоззрение, философия, добродетель, гуманизм, благо, мыслящая добродетель, добро.

\section{Abdigaliyeva L. Virtue as a Philosophical Concept}

Abstract. In a scientific article, the author draws attention to the spiritual values of a person, which determine the essence and meaning of the existence of mankind in the modern world. Recognition and acquisition of spiritual strength, good teachings, parables, immortal wise advice in the heritage of our oldest generations is considered as a natural phenomenon of continuity, which will become the basis and support of our national culture, language, mentality necessary for the direction of the future of humanity. That is why the doctrine of humanism, which goes back to ancient Turkic values and goes back to the discourse of the Kazakh worldview and Muslim doctrine, is considered in the article as the most necessary and important part of modern philosophy. The core of continuity in the history of the Kazakh worldview is the problem of humanism, which contributes to a deeper and wider knowledge of the history of national philosophy.

Key words: worldview, philosophy, virtue, humanism, good, thinking virtue, good. 